\title{
The Anglophone Crisis: The Birth of Warlords, the Impact of Warlords Activity on the People of North West and South West Region of Cameroon
}

\author{
Morgan Tebei Nwati \\ Central China Normal University, Wuhan, China \\ Email: brownmorgan732@yahoo.com
}

How to cite this paper: Nwati, M. T. (2020). The Anglophone Crisis: The Birth of Warlords, the Impact of Warlords Activity on the People of North West and South West Region of Cameroon. Advances in Applied Sociology, 10, 157-185.

https://doi.org/10.4236/aasoci.2020.105011

Received: April 7, 2020

Accepted: May 26, 2020

Published: May 29, 2020

Copyright $\odot 2020$ by author(s) and Scientific Research Publishing Inc. This work is licensed under the Creative Commons Attribution International License (CC BY 4.0).

http://creativecommons.org/licenses/by/4.0/

\begin{abstract}
Things are falling apart in Cameroon, as the marriage of inconvenience between the Former British Southern Cameroon (West Cameroon) and The Republic of Cameroon (East Cameroon) is about to explode into a violent crisis. Cameroon which is a member of the Central African community (CEMAC), shares borders with Nigeria which has an ongoing Boko Haram crisis, Chad is suffering from not only droughts but also Boko Haram crisis, the Republic of Central Africa also has political tensions, and Gabon amongst others. This article overviews the Cameroon Anglophone crisis and the Birth of warlords. The main objective of this study is to analyze the birth of Warlord, the impact of the Warlords on the people of (NW and SW), possible solutions to the crisis. In the process, the article also highlights gang violence by warlords and the Military of Cameroon, which includes: 1) Displacement of thousands of people (internal and external displacement), 2) imprisonment of thousands of civilians both those allegedly concerned and those innocent, 3) heavy loss of property by government and civilians not only in the two English speaking regions but the entire country as a whole. This article is a sociological analysis of the phenomenon, the birth of Warlords and the intensification of gang violence on the people of Northwest and Southwest of Cameroon. Using a qualitative case study based research strategy, this research investigates and analyzes the different system of government and other factors which can be used as a solution to the Anglophone crisis. The solution includes: 1) Federalism, 2) Unitary system, 3) Secession, 4) Dialogue, 5) United Nations and African Union, as actors and strategies that can be implemented in Cameroon.
\end{abstract}




\section{Keywords}

Warlords, Gang Violence, Crisis, Refugee, Federalism, Secession, Dialogue, Unitary

\section{Introduction}

The term "Anglophone Crisis in Cameroon" incorporates the various political, economic, and social problems that the former Southern British Cameroons community or the North West and South West regions of also known as (Ambazonians) have been facing since it acceded to independence in 1961 and by joining La Republic du Cameroun also known as East Cameroon in 1961. The origins and evolution of this problem are outlined in works like the following to name only a few. These works have in common the fact that they decry among others, the political marginalization of the former British Cameroonians or the Anglophones in the country, the dominance of the French language at all levels of the society, generalized poverty since the creation of the unitary state and the domineering behavior of La Republic administrative officials posted to the two English communities.

According to Searcey (2018) "Cameroon is on a brink of civil war", and issue which has been a time bomb for more than 50 years. Moreover, marriage between the British Southern Cameroon and the Republic of Cameroon was plotted with unequal standards, no legal backings and with little or no international recognition has become a real problem as the "Anglophone crisis is threating to spin out of control" (Dahir, 2018).

In 1961, the southern Cameroon entered into a two-state federation with La Republic du Cameroon as west and East Cameroon respectively, the marriage went on, and in 1972 former President Ahidjo, altered the structure of the union by abandoning federalism and transforming the country into a unitary state called the United Republic of Cameroon. This transformation holds on right up to 1984, when President Paul Biya changed the name of the country to La Republic du Cameroon which was the original name the French administered East Cameroon. Thus by dissolving the existence of the union with West Cameroon, it creates a fully French speaking nation.

Most Southern Cameroonians have lived all their lives as second class citizens, with a grouched, and a second thought of being independent like before the marriage of inconvenience. This second thought is also emphasized in the discussion on the Anthropology of Africa and the challenges of the $21^{\text {st }}$ century (Nchoji, 2015).

According to the December 22, 2016 Bamenda provincial Episcopal Conference (BAPEC), the Anglophone Archbishop of southern Cameroon, in a letter to the president of the country addresses the Anglophone problem as follows.

- The failures of the marriage between Former southern Cameroon and la Re- 
public du Cameroon to respect and implement the article of the constitution that upholds and safeguard what British Southern Cameroon brought along in the marriage in 1961.

- The high-handed management of the 1972 referendum which took out the foundational elements of (federalism) in the 1961 constitution.

- The 1984 law amending the constitution, which gave the country the original East Cameroon name (The republic of Cameroon) and there by erasing the identity of West Cameroonians from the union. West Cameroon which had entered the union as an equal partner ceased to exist.

- The deliberate and systematic, erosion of the West Cameroon cultural identity which the 1961 constitution sought to preserved and protect by a bi-cultural duration.

In October 2016, the Cameroon Anglophone Civil Society Consortium and organization made up of teachers and lawyers of North West and the South West regions of Cameroon took to the streets, partly because a high number of officially monolingual French-speaking lawyers were posted to north West South West region making French, the language used in court proceedings in the two English speaking regions of the country, and also in the write-up of judicial and administrative documents. According to Konings (2005), "a study of the politics of recognition and representation in Cameroon", shows that 2016 was the climax for the voices of the voiceless to be heard in Cameroon.

The following month, (Anglophone) teachers joined in the strike action partly to protest against an overflow of monolingual (francophone) teachers whose level in the English language is so bad and they therefore teach Anglophone pupils in French or Pidgin language. To highlight the fact (Jazeera, 2018), "Cameroon teachers, lawyers in battle for English" gave and external expression of how deep the struggle over language in Cameroon is leading the country into a divide.

Furthermore, University students join the movement calling on the government to be in line with the request of the teachers, because, most of the teachers were not going to school waiting on the government to meet up with their plights, while students on the other hand were paying bills and rents to landlords while schools were on halt. According to Human interest, 2018, "police Arrest, Tear gas UB Students", thus no one is free in the hands of the military in Cameroon.

Also moto bike-taxi rider's common called "Okada riders" and the general public got involved as tension escalated across the entire North West and South West regions or (Anglophone region), with people matching the streets of (Bamenda) the headquarter of North West and in Limbe and Buea in the South West region, in a peaceful protest calling on the government to meet up with all the demands of the lawyers and teachers. To highlight this situation Cameroon teachers and lawyers campaign for the battle for English giving and external expression of how deep the struggle of language is in Cameroon.

President Paul Biya's government responded to the nonviolent protest with a 
"heavy-hand", Cameroonian military were commanded to fired live ammunition from low-flying helicopters gunships into the local crowds, videos circulated in the social media showing and atmosphere of war as demonstrators were molested and forced to kneel on the ground. Thus, (Anyangwe, 2009), "the betrayal of too trusting a people" exposes how the former British Southern Cameroonians trusted the wrong people, La Republic Du Cameroon. The signal was clear, the government in Yaounde had no intention of entertaining the demands of the people of NW and SW. In addition, with the heavy handed manner in which the government of La Republic handled the growing tension, gave rise to Anglophone, Defense Forces in 2017, thus the birth of what we called warlords in North West and South West region of Cameroon (Ambazonia).

\subsection{Statement of the Problem}

Truly things are falling apart in Cameroon. It has been almost four years in $\mathrm{Ca}$ meroon today, women, children, the elderly all facing had times as they are being plagued by a terrible crisis. The crisis which according to many is first of its kind in the history of Cameroon, with thousands of both internal and externally displaced persons, Imprisonment of hundreds, and enormous loss of property. Thus it is a call for concern.

Therefore, this study examines how the Anglophone crisis leads to the birth of Warlords, and the outcomes of the activities of the Warlords in the NW and SW.

\subsection{Hypothesis}

This study highlights one explanatory hypotheses:

$\mathrm{Ho}_{1}$ there is no relationship between the Anglophone crisis and the different system of Government.

\subsection{Significance of the Study}

This study is an eye opener meaning, African countries and Cameroon in particular will be able to redress crisis situation by following up the history of the country in relation to the present crisis situation, thus highlighting possible solutions. Furthermore, this study analyzes different forms of government and other factors as possible solutions to crisis situation, especially in the case of Cameroon.

\section{Theoretical from Work and Methodology}

\subsection{Theoretical Analysis}

Several theories have been used to address the issues of Tension and conflicts. Understanding the relationship between tension and conflict between communities has always interested social science, particularly sociology. Karl Marx conflict theory focuses on the causes of class conflict between the bourgeoisie (the owners of the means of production and the capitalist) and the proletariats (the working class and the poor). The conflict theory therefore states that, tension 
and conflict, when resources, status, and power are unevenly distributed between groups in the society and these conflicts becomes and engine for social change in the society. In the context of Cameroon, power according to Marx will mean, the control of material resources, accumulated wealth, control of politics, and institutions that make up the society and one's social status.

The conflict theory painted a clear scenario of the Anglophone crisis. According to Marx, as the socio-economic conditions of the Anglophones worsened, they develop a class consciousness, that reveals their exploitation at the hands of the Republic of Cameroon, and they will revolt demanding changes thus Conflict. Marx also explained that, if the Republic of Cameroon does not address the issues of the Anglophone in relation to their needs there will always be conflict in Cameroon.

In addition, Robert $\mathrm{K}$ Merton developed the Strain theory to better analyze the Anglophone crisis. The Strain theory explains that deviant behaviors, is an unavoidable consequence of the distress individuals experience when they are deprived of ways to achieved culturally valued goals. For example, in the context of Cameroon, the government of Cameroon places value on the economic success of the country which is largely beneficial to mostly the Francophones, while the Anglophone minority only watch from a distance. According to Merton, some individuals in the Minority will use every means including, violence as to have a piece of the pie. Merton also explains that the society puts pressure on individuals to achieve socially accepted goals. The government of Cameroon have suppressed the Anglophone, neglected their calls for equality, justice and even freedom. Also with the heavy-handed manner in which the government handled the 2016 Anglophone teachers and lawyers protest, pushed the Anglophones to the streets to revolt against the government.

As days go by, things continue to fall apart. The warlords became bolder and stronger, more associated groups of newly recruited warlords joined the struggle. The warlords started targeting schools, government, infrastructure, and government officials. Teachers were targeted because some of them did not respect the lockdown of schools as they wanted, local chiefs were also targeted as they accused them of siting with the police. The Cameroonian military clashed with the Warlords in what is popularly known as the battle of Batibo on the 3rd of March. According to (Abah, 2018) " 4000 persons in Batibo displaced after deadly clashes between gunmen and security forces". This battle recorded unprecedented catastrophes from both the warlords and the Cameroonian military. The remains of Batibo were smoke and dead bodies all over the village. During this period the warlords suffered lots of setbacks and accusations of kidnapping foreign nationals in Cameroon. These setbacks forced the ADF to declare that, they do not target foreigners as part of their agenda.

Furthermore, throughout May, there were heavy clashes between the government military and the Warlords. Concord (2018), emphasis "three soldiers killed in Mbonge and Muyuka". National Day celebrations were around the corner, for 
the warlords to force the Ambazonians not to be part of the celebration, the Warlords had serious raids through the so call Ambazonia territory creating fear and panic in the villages of Konye, Batibo, and Ekona. Also killing and kidnapping continues to happen throughout the month of May. May 24th is remembered as the Pinyin Massacre, the Cameroon military killed more than 30 civilians in Pinyin as they stormed into a hotel which hosted people from different age groups. Mothers, children, and young adults were killed, claiming they were warlords of Ambazonia.

\subsection{Gang Violence by Warlords and Military (OUTCOMES)}

According to Guardian (2018) analysis that "this is genocide as village's burn as war rages in blood-soaked Cameroon". A country with a cruel and dictatorial regime mass killing like what is happening in Cameroon makes no news to the local media and even some international organs like the United Nations.

Besides, as things continue to deteriorate, the warlords also accumulate different strategies to resist the military of Cameroon. According to interview by the general manager of Cameroon Radio television, he explained that "Hold up in the Kumba high way keeps passengers stranded". The warlords made a blockade on the Kumba-Buea highway, a 10 kilometers distance from the Buea town. It was counter with heavy fire exchange between the Government forces and the warlords. June, July also had a major setback on the warlords as the war burst out to the various extremes of NW and SW. Cameroon military bases in small villages were attacked by the warlords as they extend their mission to make the entire territory ungovernable. V.O.A. (2018), publication explains "Cameroon military say casualties are mounting", all this can be confirmed by the numerous attacks of the military bases by the Warlords.

The NW region was characterized by serious tension in August 2018. The warlords had deadly activities in Babungo, Ngo-Kentunjia, Zhao in the Wum division killing at most 6 soldiers in crossfire hit and run guerilla warfare reports supported by Journal du Cameroon. The Cameroonian military decided to burn down the entire village as a means to retaliate on the activities of the warlords.

September was very hard on the warlords as they suffer from setbacks by the government military. The government military on the other hand, score a series of success as they were able to weed out some camps of the warlords. Zhao camp was attacked, 27 suspected warlords were killed, another raid took place in Chomba and 15 suspected warlords were also killed.

On the other hand, the warlords had a coordinated attack in Oku, where they overran the local police station, attacked and burned down the assistant Divisional Officers' belongings, stealing a police van and abducting three police officers. Also in the same September, the Warlords pushed the police and gendarmes to retreat from Balikumbat and Ngo-kentujia.

The government of Cameroon imposed a 48 hours curfew on the 30th of September 2018, since the government knew the 1st of October will be a first anni- 
versary for the people of Ambazonia. The government wanted to avoid unnecessary mass demonstrations and celebrations. All movements were blocked, all business short down, moto parks closed, as people were forbidden to be seen in groups of four. According to an international crisis group analysis, the clashes between the government and the warlords are very lethal as the warlords were very active in 12 divisions of the NW and SW. The ADF alone had clashed with the government forces more than 85 times. This also explained that the Cameroon military is finding its difficulties in defeating the warlords despite their lack of access to proper weapons and other supplies. On the other hand, the warlords are not militarily strong enough to defeat the military. As the war continues, the Warlords effectively had their activities in all the Sub Divisions in the so call Ambazonia. They controlled more than $70 \%$ of the NW and SW regions of the country.

As presidential elections were around the corner, 7th October 2018 was the day for voting for the new presidential candidates. According to the Warlords, the Cameroon government is planning to carry out and illegal election in their country. On the part of the Cameroon government, it was affirmed that the warlords are a group of terrorist inciting civilians to commit crimes of treason against the government of Cameroon. (Guradian, 2018), publication of $7^{\text {th }}$ October analysis that, "gunfire in Anglophone Cameroon deters voter on polling day". The Entire October was characterized by gun battles all over the NW and SW regions. As a result, most of the villages of the NW and SW were all deserted as the voting day comes closer. Warlords were seen moving freely around the rural areas and in some parts of the urban areas of Bamenda and Buea preventing people not to take part in the Presidential elections. Before the end of October, the Cameroon military had launched a series of attacks on the camps of the Warlords. Some of the battles lasted for 24 hour nonstop gun battles (Searcey, 2018). "Cameroon on the brink of civil war as English speakers recounts unbearable horror". This was in confirmation of the 25 warlords killed with an unknown number of the military killed and injured.

November was a tough month on the Warlords, as they suffered setbacks from as the government military slaughtered a good number of their fighters. Because of the crisis, Moki (2018), analysis that, "Separatist kidnapped 79 pupils in Cameroon restive northwest". Students were kidnapped from, their school in kwen a village closer to Bamenda town. The Cameroon government accused the Warlords of using kidnaps as part of their plan to terrorizing the local population. The Ambazonia Self Defense Council which is the most active wing of the warlords, on the other hand, debunked such accusations made by the government and even chose to send some of their soldiers in search of the missing students. Cameroun (2018d), on its 12th October 2018 reports explains "Principal of PSS Kwen and three others released", as pressure mounts on the entire NW and SW region of the country.

On the 11th of November, according to the Warlords, 13 soldiers from the 
government and 2 warlords were killed in a successful ambush. The next day which is 12th November, Cameroun (2018c) confirms, "Cameroon soldiers ambushed and killed 13 suspected warlords in Mbinka Donga-Mantung", and 25 suspected warlords were slaughtered near Kamba as videos circulating on social media.

On the 22nd of November, over 40 warlords and unarmed civilians were killed in Bali. According to the Bali people, something was mysterious about the attack. Those killed were burned to ashes as the local population claims a chemical weapon was used against the people. Also, there was tension in the West region of Cameroon, at least 30 people were kidnapped in Cameroon West region by unidentified gunmen in Bangourian and were transported by canoes across Lake Bamendjing reservoir. Bangourian was attacked by the army finding no trace of warlord activity in the area.

December started with tension and chaos, as the government military attacked and burned the entire villages of Romania, kikiakom, and part of Ekona. Also due to the in-house fight by the warlords concerning leadership, 5 fighters were executed by the Warlords. This led to instability in leadership. According to the Cameroun (2018b) report of December 21st, supports the fact, "Ambazonians General killed in Kumba" General Ivo Mbah was killed during a military raid in Kumba. He was on the top must want dead or alive list in Cameroon, but contrary to the Ambazonians he was their must trust, worthy general.

On December 31, both the leaders of the so-called Ambazonia and the president of the Republic of Cameroon addressed the nation. President Paul Biya the 85-year-old dictator who just got re-elected into office for another 7 years mandate, said as confirmed "soldiers will neutralize all the terrorists who fail to disarm" and those who disarm will be treated and welcome back into the society. On the other hand, Cameroun News Agency (2018) validates President Samuel Sako Ikome as he said "no retreat no surrender from defense to offense" the way forward for the warlords. President Sako Ikome also condemned all those involved in kidnapping civilians, "we will fight back against such practice" Sako Ikome.

Furthermore, the government military also announced the killing of Oliver, mystery surrounds Reported death of Ambazonian field marshal of the Red dragon's militia in Lebialem. This announcement was denied by the interim government of Ambazonia as Oliver resurfaced in a video one week later, the false announcement.

2019 as described by many Cameroonians is a year of empty villages and even some urban areas, especially in the NW and SW regions. There was a mass movement of Cameroonians from the two English Regions to other parts of the country with no tension or crisis. Both private and public institutions of learning have been inactive for more than three years. The population of youths out of school was more than $60 \%$ as analyzed by UNICEF United Nation Children Emergency Fund of 7th January 2019. 
Furthermore, as the war continues the English speaking Cameroonians both at home and in the diaspora organized protest activities to mark the first anniversary of their leaders in jail as verified by Cameroun (2019c), in it 7th January news release. Later that same day, clashes took place in Muyuka, Bafut, Mundum, and Mamfe. Journal du Cameroon upholds the fact "Ambazonian General killed in Matoh". In Mamfe two warlord generals were killed as their camps were raided by the Rapid Intervention Battalion. On the 24th January General, Andrew Ngoe of SOCADEF was killed in Matoh, Mbonge.

January also started with the trial of the leaders of the Ambazonia, including Sesiku Ayuk Tabe who had already spent 1year in prison. The trial was complicated as the Nigerian Court condemned the deportation of the Ambazonia leaders from Nigeria as unconstitutional and ordered their return to Nigeria. Journal $\mathrm{du}$ Cameroon highlights "Nigerian Court orders the return of Ambazonian leaders" her 1st February 2019 news release. Never the less, the government of Cameroon ignored such claims and continued with the trial. On the same day of the trial, the entire NW and SW were almost deserted as everyone stayed indoors. "Violence, Gunshot, ghost towns engulfed part of Anglophone towns" as explained my former Mayor of Buea Ekema Patrick on a radio interview on the $10^{\text {th }}$ January 2019.

On the 4th of February, in anticipation of how to interrupt in the 11th February youth day activities, "Ambazonian separatist imposed a 10-day lockdown of the Anglophone region" confirmed by Cameroun (2019e) that is from the 4th to the 14th of February. Most parts of the SW were lockdown with serious clashes taking place in Muea and Muyuka. Also, the entire NW region witnesses a serious lockdown while there were clashes between the government military and the warlords almost everywhere in the region. In Muyuka, according to 6th February Cameroun (2019a), new release, "Ambazonian colonel killed in Muyuka" alongside two warlords, in Bengwi two warlords died while attacking the Divisional office. As a result of the lockdown gunshots frustrates youth day activities and also forced Buea University to postpone its opining date. The celebration was a sham as it was boycotted by most cities in the so-called Ambazonia. Buea, Kumbo, Belo Ndop, Wum, Mamfe, Tombem Mundemba, and Lebialem all these cities boycotted the 11th February celebrations.

March was characterized by several roadblocks including an overnight mission by the Seven Kartas Warlords. Ambazonian fighters erect a wall in Bafut, and the Warlords blocked the Bamenda Bafut high way with concrete walls. On the 14 of March the Cameroon soldiers burned down several houses in Dunga Mantung and Menchum, and dozens of people were burned alive.

At the beginning of April, one of the leaders of ADF said they will push the battle into the French region of the country. A week later Penda Mboko, the littoral region was raided by some unidentified gunmen. On a contrary note, (Bareta, 2018) "Interim government Warns Cameroon against propagating inter-citizen war between both Cameroons". 
On the 14th of April, there was a gun battle in Bali between the warlords and the Cameroon military. Four Cameroon soldiers were killed and three Ambazonian warlords were also killed. The next day, there was a series of brutal arrests and killings in Buea as the soldiers were in search of a hideout or a camp for the warlords. On the 27th of April, SDF Chairman Ni John Fru, Ndi the main opposition leaders of the Social Democratic Front (SDF) was kidnapped and released the same day in Kumbo. He went to attend the funeral of his friend Joseph Banadzem. On the 30th of April, the Cameroon soldiers burn down several houses in Kikaikeliaki and Bui.

The Anglophone crisis by this time has been going on with thousands of death, thousands of internally and externally displaced persons, violations of international treaties by the Cameroon government. None of these worries stroke the attention of the international community.

On the 5th of May 2019 thousands of Ambazonians as they called themselves were happy when they, read on newspapers, European Union parliament, announced that the Anglophone crisis will be debated in the United Nations Security Council. A few days later, according to 9th May Cameroun (2019d) report, "Paul Biya ready for dialogue to end Anglophone crisis". The Government of Cameroon announced they are ready for an inclusive dialogue, wherein everything but not the independence of Ambazonia will be discussed. Also, there were inner squabbles between the warlords concerning leadership, which divided the camp with warriors picking sites.

It was great news for the warlords to say, they have started producing their weapons, on the other hand, it was news for the Cameroon military, as they confirmed such allegations (V.O.A., 2018), press news released, "casualties mounting are because fighters are well armed". A few days afterward, a mine killed four police officers and wounded six, there was evidence that the warlords are well-armed.

On the 27th of June, SDF chairman John Fru Ndi was kidnapped and released. It was the second time in two months the opposition leader was held captive by the warlords. By the end of June, there were rumors about the government of Cameroon planning to negotiate with the warlords to end the war.

July was tough on both the Warlords and the Cameroonian military. On the 3rd of July, warlords attacked a military boat carrying 13 soldiers on river Ekpambiri in the Manyu Division, seven of the soldiers mysteriously disappeared one found dead after five days and two managed to escape. On the 9th of July, warlords Ambushed and killed three soldiers while several of them were wounded in Ndop. On the 11th of July, seven warlords were killed in a village in NW called Esu, one soldier from Cameroon military was also killed on the 14th of July in Buea. The warlords also suffered lots of setbacks within their circle as there was infighting amongst fighter warriors.

On the 22nd of July Ambazonian inmates at the Kondengui central prison started a protest against the deteriorating prison condition, especially on the 
poor health and nutritional services offered by the prison. The Pretest later changed into a riot, which was violently contained by the forces of law and order. According to 24th July (Cameroun, 2018a), report, "Anglophone detainee missing after Kundengui protest", set a pace for Ambazonians in different prisons to react similarly. Inmates in the Buea central prison had a similar strike action which was violently quelled down, with speculations that some of the inmates were killed by the government of Cameroon. The Interim Government and most of the Ambazonians leaders, including Sesiku Ayuk went on a hunger strike. Cameroon News Agency confirms "Ambazonian separatist leaders give government automaton to present to present detained prisoners".

To sabotage the upcoming academic year, on the 14 of August the warlords announced, a region-wide lockdown will be implemented on the $2-6$ and $9-13$, covering the first two weeks of school resumption. BBC, report of September, 2nd 2019 "Cameroon's crisis keeps school shut". The school year never took up as plan as thousands of kids have been displaced both internally and more externally as the crisis worsened.

On the 15th of August, the Cameroon rapid intervention Battalion military truck had a serious accident on the Kumba Buea high way. The Warlords later claimed it was a result of a road mine, thus proving they make their weapon and use them.

Ambazonian leaders were handed life sentence, ten members of the interim government of Ambazonia including Sesiku Ayuk Tabe were tried in the military tribunal in Yaoundé and were sentenced life in Prison. This trial had a wrong timing as there was increased tension across the NW and SW and series of lockdown downs. This move frustrated all the hope, to rekindle the academic year. August 26th (V.O.A., 2019a), analysis that, "Thousands Flee voiceless in Cameroon English speaking region" thousands of people from NW and SW flee for their dear lives as things continue to fall in pieces.

There were constant military raids in almost every neighborhood resulting in the death of hundreds of youths especially boys who were above the 14 years. According to most parents, their sons were targeted by the local police as most of them were found lifeless after military raids.

President Paul Biya announced a Major National Dialogue to be held before the end of September. On the other hand, most of the Ambazonians and warlords especially rejected the dialogue platform, because their leaders are all in jail and they claim it is a monologue since not every issue is accepted at the platform. Biya's dialogue to solve the Anglophone issue runs into question, and rejection, while opposition leaders, on the other hand, saw the dialogue as a means to settle the problem as most of them started submitting proposals to resolve the Anglophone crisis to the head of government.

The war continues, the warlords had a failed plan as they attacked some government officials in a hotel in Bamenda which did not work as planned. While the National Dialogue was taking place, confirms in her press release, (V.O.A., 
2019b) "Cameroon separatist celebrates independence as dialogue is held". On the other had Ambazonians were celebrating their second independence on October 1st. Nine people were killed all over the Ambazonia territory during their independence celebration. While in Lebialem Field Marshal Oliver Lekieka of the Red Dragon militia declared himself the paramount ruler of Lebialem. By the end of October, there was a significant exodus of Youth out of the NW and SW region of Cameroon. Most villages were empty, as nearby French-speaking region of Baffousam, littoral was flooded with thousands of homeless families.

The warlords of Ambazonia had their first trail in attacking a Camair-co-passenger airplane because of the fact, Cameroon News Agency, explains, "Attack on Camair-Co passenger plane shows nothing is under control", December 1st, 2019 new report. The Warlords explained that anything carrying soldiers is their target. Even though no one was injured but several bullets penetrated the plane as it landed in the Bamenda airport. This was a message to the Cameroon army that, they are ready to attack even bigger war vessels.

The warlords also started their operation calling on the Ambazonians not to take part in the upcoming 2020 Cameroon parliamentary election. The leaders of Ambazonia are claiming the upcoming election is illegal. In less than a week the warlords abducted more than 40 politicians and 19 councilors. December 19 was a great mass raid by the Cameroon military in Mezam, Boyo, Donga Mantung, Bui and Ngo Ketunjia was raided by the military. Accordingly, massive population displacement took place in the North West. More than 10,000 people had to flee their homes in less than a week as recorded by locals of the area.

The year 2020, started with, tensions rising from the upcoming parliamentary election in February. In the SW region especially in Buea and Muyuka, clashes break out, the Divisional Office was burned down even though no loss of lives, more than 6 Warlords were injured. Also, there was an in-house crisis between the warlords as some fighters were accused of terrorizing the local community which they represent.

On the 6th of January General Divine was killed by his people, because he incited fear and terrorized the people of Balikumbat and Babungo. The ADF ordered the warlords to fight against or take action against anyone terrorizing the people. The end of January was characterized by a series of infighting between the warlords to date. The Southern Cameroon restoration forces loyal to the Interim Government abducted 40 fighters from the ADF six of whom were killed eventually, this raid was carried out under the leadership of General ChaCha. Chacha who was later executed by the Cameroon military some week's letter.

February parliamentary election was marked by a high level of tension between the Cameroonian Government and people of Ambazonia as most. Military personnel was deployed all over the NW and SW region. On the other hand, the Warlords abducted 120 politicians, in less than weeks to the election.

Despite all measures put in place by the government of Cameroon as not to repeat what happens in the 2018 election with poor participation especially in 
the NW and SW region, the Ambazonians claimed 98\% of their population boycotted the election and hailed as a great victory.

UNICEF briefings of 2019, upholds that Geneva Palais briefings note on the situation of children in the NW and SW region of Cameroon. Even though the United Nations is aware of what is going on in Cameroon, the whole world still had a passive stance on the issue.

Unfortunately, 14th of February 2020 will forever be remembered by the people of Ngarbuh as 32 civilian's mostly young children, pregnant women and some few elderly people were massacred by the Cameroonian soldiers in Ntumbo NW region of Cameroon. It was a dark period for the people of Ambazonia.

The Anglophone problem: The Birth of Warlords, the Intensification of Gang violence and Its outcomes on the two English speaking region (North West and South West) of Cameroon.

\subsection{Methodology}

The choice of Cameroon as the case study is very relevant because the of country's image, from the most peaceful to one of the most unstable counties in central Africa. For instance, from 1961-2016, West Cameroon and East Cameroon have co-existed with no major Problems despite their cultural and historical differences.

Also the country is having a huge population shift as thousands of people from the North West and South West have flee their homes because of the crisis. 530,000 internally displaced people, and 444,213, externally displaced people suffering at the border towns in Nigeria, OCHA December 2019. Also in the Northern regions of the country, there is serious problem as the Boko Haram still destabilize the peace creating thousands of displaced people, both from Nigeria and from Cameroon, adjacent to Cameroon which is the central Africa is also a conflict zone.

The article adopts a qualitative methodology for empirical/primary data collection in Cameroon. Empirical primary data were obtained from various sources-technical reports, official documents and open, semi-structured interviews (Bhattacherjee, 2012).

This research follows, a purposive sampling criterion (Etikan, 2016) and identifies 30 interviewees from the different sectors in the community 15 men and 15 women, who are directly or indirectly involved in policy formulations and implementation, administration and governance. The sampling criteria are focused on very experience stakeholders, (those who are currently in the public sector, those who have retired from the public sector), influential sole proprietors, and universities student. During the data collection process in 2019, some ten top/high-ranking and mid ranking stakeholder (selected from the 30) were interview who meet the respective sampling criteria. With the bilingual nature of Cameroon (French and English), the interviewee was interviewed in their language of choice. There was no need of interpreters because the interviewer must understand both languages. The interview lasted for $45-60$ minutes as to fully cover the depth of the in- 
quiry. Since the topic is the talk of the day in Cameroon, respondents were able to engage passionately in the dialogue while exploring similar crisis management themes due to the semi-structured nature of the discussion (Creswell, 2011), thus data was generated that was beyond the score of this article.

The key interview themes were centered on aspects which concerns the form of the state of Cameroon. The aspects include, a unitary government, a Federation, a Republic and also Secession. Secondary source of information was obtained from reports on the Anglophone crisis, academic journals, books, policy documents. Status reports on the Anglophone crisis were available as source. International conflict management agreements, conference proceedings, declaration and speeches, were all review to have insight of the Anglophone crisis as to bring out possible solutions.

The second phase (field research validation) is executive briefings. The briefing served as a peer review and bench learning exercise. Preliminary findings were presented, analyzed and scrutinized, to ensure their validity. The entire project adhered to strict ethical procedure, participation was voluntary and to the convenience of the participant.

\section{Findings}

Building on the causes of the Anglophone crisis, finding suggests the existence of a number of possible solutions which can help resolve the Anglophone crisis. These proposals can be used to bring peace, solidarity and Unity amongst Cameroonians. The following findings were registered federalism as a solution to the Anglophone crisis.

In 1961, the state of West Cameroon and East Cameroon came together in a referendum and formed a Federal government. This system of government was practiced for more than a decade in. Thus this system of government is not new to Cameroonian.

\subsection{Do You Think the Federal System Is a Solution to the Anglophone Crisis?}

According to the findings, Table 1 shows that more than $80 \%$ of the sampled population responded to Federalism are a solution to the Anglophone crisis. The answer was further expanded; three types of federalism were presented to the respondent: a two-state federal system, a ten-state federal system and a four-state federal system.

\subsubsection{The Different Types of Federalism}

Figure 1 shows that a two state federal system is presented as the leading solution in terms of the different system federal government presented. (70\%) of the respondent said a two state Federation is the best way forward. Some said the structures of a two State Federation are "already operational" since it is not a new concept in Cameroon. In 1961 the former British Southern Cameroon jointed the Republic of Cameroon to form a Federal Republic of Cameroon. 


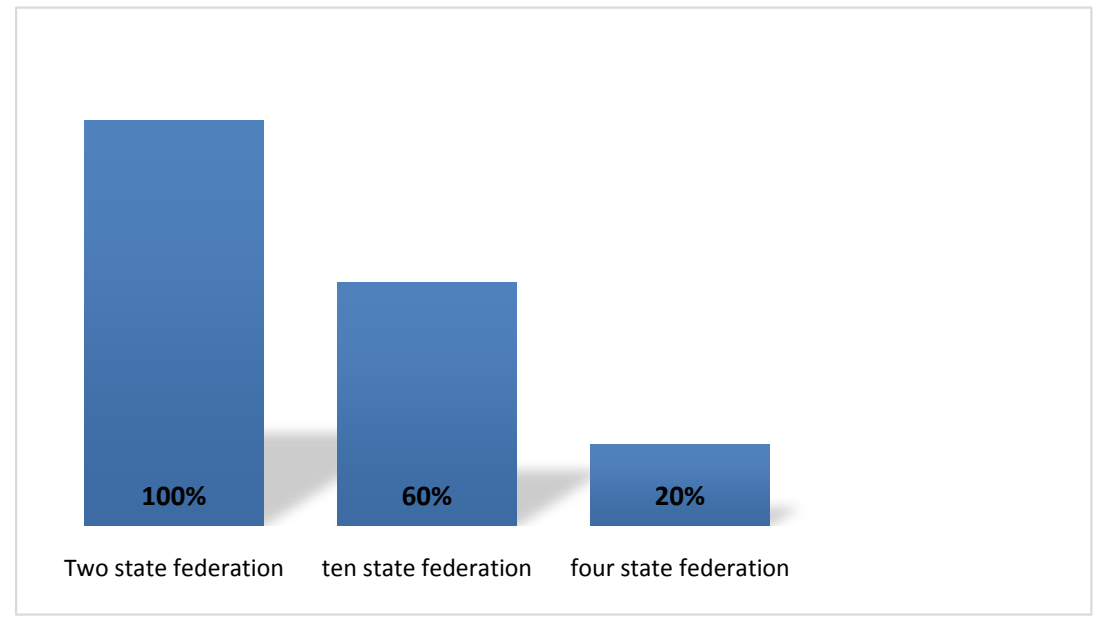

Figure 1. The different types of federalism.

Table 1. Do you think the federal system is a solution to the Anglophone crisis?

\begin{tabular}{ccccc}
\hline Validity & Frequency & Percent & Valid Percent & Cumulative Percent \\
\hline No & 5 & 17.2 & 17.2 & 17.2 \\
Yes & 24 & 82.8 & 82.8 & 100.0 \\
Total & 29 & 100.0 & 100.0 & \\
\hline
\end{tabular}

Respondents also emphasized that with a two state federal system, the historical, political and cultural values of each state will be maintained. This further solved the issue of decentralization as each state will "be responsible" for the growth and development of their region. Eighty percent of the respondents cited the period in Cameroon history when, Southern Cameroon joyfully agreed to joint with the Republic of Cameroon in good.

\subsubsection{Unitary System as Solution the Anglophone Crisis}

Interestingly, Table 2 bellow idealizes that some of the respondents say, a unitary system of government, is also a positive solution for the Anglophone crisis. In 1972 President Ahmado Ahidjo replaced the Federal system with the unitary system of Government. This system of government lasted for more than a decade, from 1972-1984. The unitary system of government marks a turning point in the history of Cameroon.

\subsubsection{Do You Think the Unitary System Is a Solution to the Anglophone Crisis?}

For those who responded that unitary system of government is a solution to the Anglophone crisis were give presented with three other factor favoring the Unitary system. Table 2 shows the different responses in relation to the different patterns of identity.

\subsubsection{Patterns of Identity}

The identity pattern was seen as a very significant factor in maintaining national 
unity, sixty percent of the respondents said a unitary system of government will facilitate, indigenous cultural exchange and will enhance a greater individual and cultural efficacy. In addition, some respondent said the unitary system will constitute the basis of national awareness or to make socio political interaction natural.

\subsubsection{Patterns of Functional Interest}

According to some respondents, functional interest is those political concerns which shape the unitary system. These interests are relevant to the operation of the whole system, not only those individual who seek to monopolize and control political powers. In the Unitary system according to one respondent, political interest is distributed in a platform where all the different stakeholder is accountable to every decision the make as they represent an immediate community.

\subsubsection{Patterns of Political Interaction}

The Unitary system according to some respondents, is being powered by the pattern of political interaction. When Cameroon was a Unitary state, the level of interaction between the two governments, had "meaning". Political, economic and cultural interaction was on a pace of equality and respect. $10 \%$ of the respondent express, political interaction in a unitary system establishes high level of interaction and undistorted political (Figure 2).

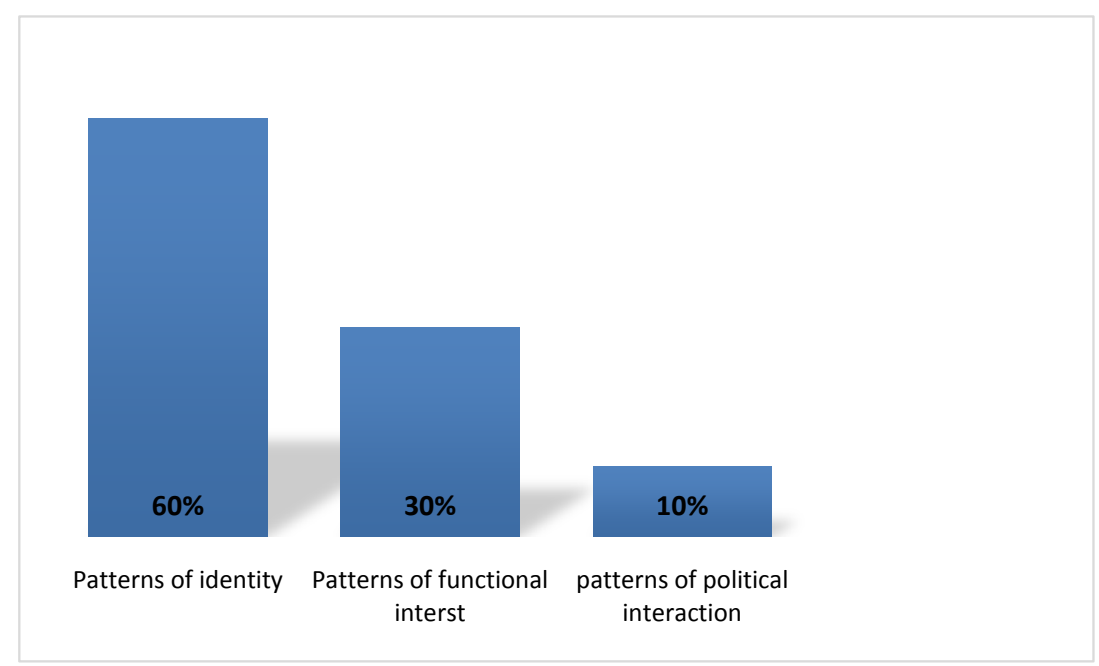

Figure 2. Factors favoring the unitary system.

Table 2. Do you think the unitary system is a solution to the Anglophone Crisis?

\begin{tabular}{ccccc}
\hline Validity & Frequency & Percent & Valid Percent & Cumulative Percent \\
\hline No & 14 & 46.7 & 46.7 & 46.7 \\
Yes & 16 & 53.3 & 53.3 & 100.0 \\
Total & 30 & 100.0 & 100.0 & \\
\hline
\end{tabular}




\subsubsection{Cameroon as a Republic as a Solution to the Anglophone Crisis}

In addition, the respondents were also presented with the current state of affairs, do you think Cameroon as it is, the Republic of Cameroon is the solution to the Anglophone crisis? When President Paul Biya took over from Amahdo Ahidjo, in 1984 president Biya Changed the name of the country to the Republic of Cameroon, thus was not a new concept to the East Cameroonians (French speaking part of the country), because French Cameroon had practiced this system of government before her Independence. For the West Cameroonians, it was Suppression, Marginalization and a black to black colonization. Most west Cameroonian knew the French system will dilute the minority West Cameroon (Anglophones).

\subsubsection{Do You Think Cameroon as a Republic Is Solution to the Anglophone Crisis?}

Table 3, shows a very negative responds as most of the respondents were against the current form of government. Most of the youths in Cameroon are not represented in the affairs of the state and see the present the government as a failure. High youth unemployment, poverty, increase crime, poor social amenities amongst others.

Furthermore, since the issue of the Anglophone crisis, is a current event and the present status of country is the Republic of Cameroon, other variables such as occupation, were put into question.

\subsubsection{Occupation}

According to international labor organization of 2019, Cameroon youth unemployment is a call for concern, Cameroon like most African countries have a youthful population. Unfortunately, the ILO indicates a 5.5\% rate of unemployment in Cameroon. From a lay perspective, it will mean a very low unemployment number. But the main concern in Cameroon is the issue of underemployment. Table 4 shows a high $\%$ of responds saying the provision of jobs to Cameroonians will be a positive solution to the ongoing crisis in Cameroon not only in the Anglophone region but the entire country.

Table 3. Do you think Cameroon as a Republic is solution to the Anglophone crisis?

\begin{tabular}{ccccc}
\hline Validity & Frequency & Percent & Valid Percent & Cumulative Percent \\
\hline No & 24 & 80.0 & 80.0 & 80.0 \\
Yes & 6 & 20.0 & 20.0 & 100.0 \\
Total & 30 & 100.0 & 100.0 & \\
\hline
\end{tabular}

Table 4. Occupation.

\begin{tabular}{ccccc}
\hline Validity & Frequency & Percent & Valid Percent & Cumulative Percent \\
\hline Public & 12 & 40.0 & 40.0 & 40.0 \\
Private & 13 & 43.3 & 43.3 & 83.3 \\
Student & 5 & 16.7 & 16.7 & 100.0 \\
Total & 30 & 100.0 & 100.0 & \\
\hline
\end{tabular}




\subsubsection{Religion}

Also the issue of Christianity is another important variable which must be question in the case of Cameroon. Cameroon has a heterogynous population of over $60 \%$ Christians and $40 \%$ Muslin. The issue of religion in this modern time, clarifies the stereotypes which most people classify African warfare to be mostly driven by superstition and local tribal conflict. But in a context like Cameroon one will be forced to look check on religious factors. Table 5, indicates that most Christians responded than muslin clarifying that since the two English Regions is dominated Christians, they will respond more than the Muslims. But the situation in Cameroon is not only limited to the Anglophones, but a general problem which most people classify the government as a failure.

\subsection{Secession as a Way Forward}

Another form or a system of government that many Cameroonian had thought of but which never happened was Secession. Most Southern Cameroonians or West Cameroonian as I may say, thought of secession as a way forward. Some even argue that, in 1961 during the plebiscite, the option of secession was never mentioned or brought up for the people to choose. According to December, $28^{\text {th }}$ (Nationalia, 2017), publication "Southern Cameroon crisis has marginalized Anglophones seeking independent republic". But on the 1 of October, the Southern Cameroons National Consortium United front, declare the independence of the Republic of Ambazonia.

Table 6 shows that, most people don't really buy into the idea of secession. The valid percent shows a $60.3 \%$ no, most Cameroonians don't really like the option of secession even though most Anglophone think of secession as the last option. There have been more than 60 years of intermarriage, blending of cultures, spiritual rights and with cross country developmental projects in Cameroon. The following conversations were recorded concerning the idea of secession as a way forward.

\subsubsection{Rapid Growth in the Socio Political and Economic Sector of NW and SW}

One respondent said, there will finally be "peace" in the NW and SW region of the country. Some Respondent also explained that the NW and SW region of the, contributes to more than $60 \%$ of the entire GDP of the entire country $39.2 \%$, from natural oil and gas, $12.3 \%$ on cocoa and coffee beans (Cameroun, 2019b) report. Some also said, with stand point NW and SW will have more resources to manage their own affairs. Most of the respondent said the, the issues of the size of NW and SW will never be a problem as they quoted, NW and SW is larger than Equatoria Guinea, which is neighboring country to Cameroon. One respondent also said seceding from La Republic du Cameroon also mean opening the NW and SW to International trade which trigger socio economic development of the region. Thus the problem of youth unemployment will be in control as more youth both home and abroad will be welcome back in the country. 
Table 5. Religion.

\begin{tabular}{ccccc}
\hline validity & Frequency & Percent & Valid Percent & Cumulative Percent \\
\hline Christian & 20 & 66.7 & 66.7 & 66.7 \\
Muslim & 9 & 30.0 & 30.0 & 96.7 \\
None & 1 & 3.3 & 3.3 & 100.0 \\
Total & 30 & 100.0 & 100.0 & \\
\hline
\end{tabular}

Table 6. Do you think secession is the solution to the Anglophone Crisis?

\begin{tabular}{ccccc}
\hline Validity & Frequency & Percent & Valid Percent & Cumulative Percent \\
\hline No & 19 & 63.3 & 63.3 & 63.3 \\
Yes & 11 & 36.7 & 36.7 & 100.0 \\
Total & 30 & 100.0 & 100.0 & \\
\hline
\end{tabular}

\subsubsection{Reconstruction of the Identity of the Anglophones}

Respondents in favor of separation said, the cultural "heritage" of the people of NW and SW will once again be "restored". Another respondent said the language, education, and the justice system of the Anglophones will be restored. These factors are the main reason for the Anglophone crisis. Another respondent said, during the just ended peace submit in France, Cameroon president Paul Biya declared there were key differences between the French and English speaking Cameroonians because of their contrasting experience under colonial rule. Paul Biya also reveal that, "we had the possibility of integrating the English speakers directly into the Francophone system, which was predominantly used by $80 \%$ of our people, I believe, countries are now concerned about their identity, that is why we are setting up a special status recognizes the specificity of the English speaking area", journal du Cameroon, $21^{\text {st }}$ January 2020. These are all reason for separation because it was "black to black colonization".

\subsubsection{Repatriation of Anglophones}

Thousands of Anglophone based abroad will finally find their way back to NW and SW one respondent said. One particular respondent claims, separating from La Republic du Cameroon will mean bringing expert knowledge especially from the Anglophones who ran away from Cameroon because of poverty and Unemployment. One respondent said the government of Cameroon is based on "man know man" meaning if you don't have any relative working in the government, it will be impossible to have a job from the present system. One particular respondent said, separating from Cameroon will give breading grounds for more developmental ideas as most of the youth of NW and SW use continues education as a means to run away from Unemployment. This will imply more youths in the active.

\subsection{Other Factors (Perceived)}

\subsubsection{Government's Recognition of the Crisis}

Besides, sixty percent of the respondent said the government should recognize 
that there is an Anglophone crisis. One particular respondent said, the crisis we have today is because of failure of the government in recognizing the problem. Another respondent said if the government had address the issues of the lawyers and the teachers in 2016 with a peaceful approach, there will be no crisis today. The president of the Republic of Cameroon should publicly recognize the Anglophone problem as to calm down tension in the country. Another Respondent said, there is the lack of political will by the Cameroonian politicians. The government of Cameroon is too powerful to extend no politician will be able to "risk it all”.

\subsubsection{The Release of the Anglophone Leaders}

"The leader of Cameroon separatist movement has been arrested by Nigeria's intelligent service, a source told the BBC". He was arrested with 46 others. From 2016 till date, there have been countless arrest and abductions by the Cameroon Military. News on the streets say "some do not even make it to jail as they are being killed" and dump on the streets. More than $50 \%$ of the respondent were in favor of the government to release the leaders of the Anglophone movement. And all those who have been sent on exile because of the crisis should be welcome back home.

\subsubsection{Sanctions to Defaulters of the Law}

All those who have committed crime against humanity should be sanctioned. The heavy-handed manner in which the Cameroon government took to calm down the peaceful demonstration in 2016 gave rise in the crisis we have today. Both the government and the separatist movement, have committed serious crimes against Humanity, according to Human Right Watch of July 2018. "Abuses by Government and separatist groups in Cameroon's Anglophone region, these killings can be stopped". More than $80 \%$ of the respondent blame both the government and the Warlords for committing all the crime against Humanity.

\subsubsection{The Reconstruction of Bilingualism}

More than $80 \%$ of the respondent said Cameroon has lost its touch of bilingualism. One respondent said, very few people in the world even knows Cameroon as a bilingual. Another Respondent said Anglophones have been talking about marginalization and suppression by the Francophone for a very long time. But it is time for the government to reconstruct and organize the National Commission on Bilingualism and Multiculturalism, so that both the Anglophones and Francophone should be represented equally as to have equality and power in decision making.

\subsubsection{Reorganization of Administrative Institution}

The Cameroon government, should re-organize both the local and senior administrative institutions of Cameroon as to better represent and reflect the demographic, political and historical importance of the Anglophones in Cameroon, to welcome youth and more legitimate members of the Anglophone 
community. More than $60 \%$ of the respondents said the, Anglophones are under-represented in Cameroon. One respondent said the Cameroon Government is "man know Man" meaning, if you do not have a relative anywhere you will not go anywhere, as concerns to public service.

\subsubsection{Dialogue}

When the Anglophone crisis exploded in 2016, the most common demand of the people was dialogue. Before the crisis escalated into violence, the leaders of the Anglophone movement wanted the government to create a platform of dialogue. This idea was turned down by the government of Cameroon. But on the $10^{\text {th }}$ of September 2019, President Paul Biya, made a speech saying by the end of September there will be a national dialogue between the Government of Cameroon the Anglophone delegation. The dialogue lasted for five days. The following resolution;

- The adoption of a special status for the NW and SW.

- The restoration of the house of traditional Chiefs.

- The election of local government.

- The immediate relaunch of certain airports and seaport project in the two region.

- Rapid integration in the two regions.

- Rapid integration of ex-combatant into the society.

- The name of the country returns to the "United Republic of Cameroon".

Figure 3 illustrates others factors which can be considered as possible solutions to the Anglophone crisis. Amongst all, dialogue was outstanding with all respondents calling for the government of Cameroon to engage in a meaningful dialogue with people NW and SW. When the crisis in 2016, started dialogue was the ultimate solution. But as the crisis deepens, the use weapons changed the interface of the crisis. Recklessness in the part of the government and local politicians has pushed the two English speaking regions to think of secession as a way forward.

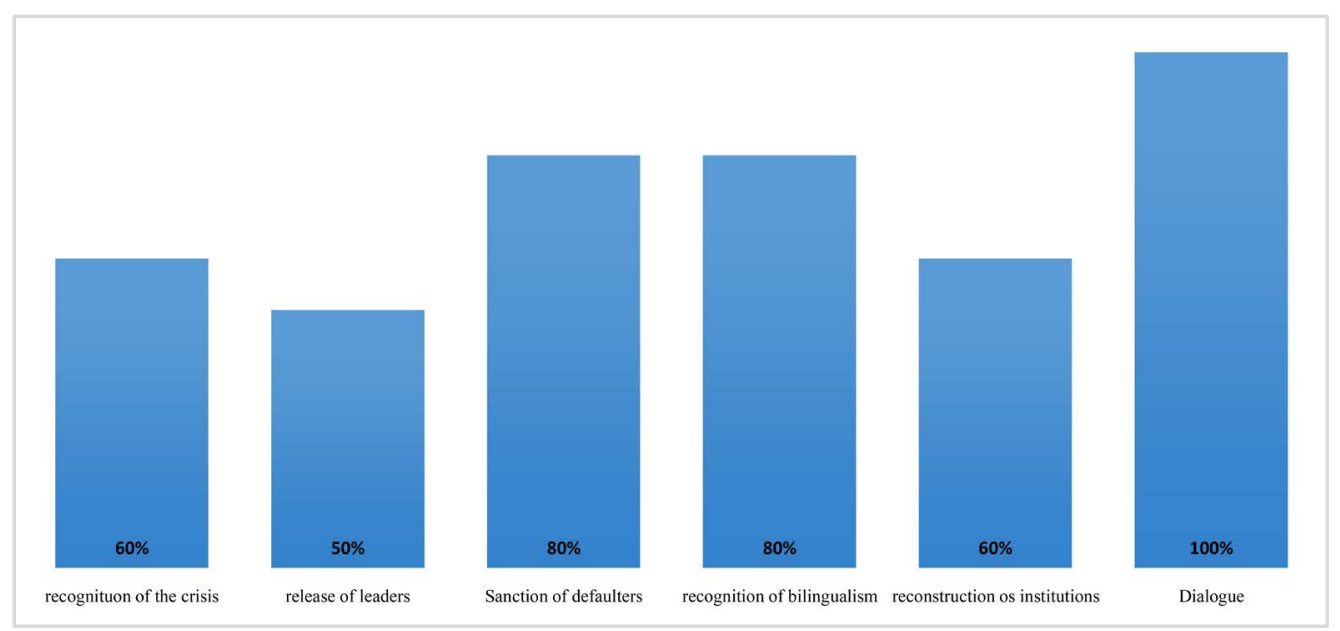

Figure 3. Other factors. 


\section{The Relationship between Demographic Factors and Federalism as a Solution to the Anglophone Crisis}

Table 7 above shows a correlation between demographic factors and Federalism. The correlation gives a significant relationship meaning, the federal system is a positive solution to the crisis in Cameroon. Figure 1 above shows a more than $80 \%$ responds rate favoring federalism as a possible solution to the crisis, thus Federalism can be proposed to the government of Cameroon as a solution to the Anglophone crisis.

\subsection{The Relationship between Demographic Factors and the Unitary System as a Solution to the Anglophone Crisis}

Furthermore, Table 8 displays the relationship between demographic factors and the unitary system as a solution to the Anglophone crisis. The correlation is significant thus the unitary system can be seen as a possible solution to the crisis. Besides, in 1972 former President Ahmado Ahidjo, changed the system of government from a Federal system to a Unitary system of government. In Cameroon the unitary system of government was practiced for more than a decade until President Paul Biya Changed the system of Government in 1984. Thus the Unitary system of government is not a new concept in Cameroon.

Table 7. The relationship between demographic factors and federalism as a solution to the Anglophone crisis.

\begin{tabular}{|c|c|c|c|c|c|c|}
\hline \multicolumn{7}{|c|}{ Correlations } \\
\hline & & Gender & Age & Religion & Occupation & $\begin{array}{l}\text { Do you think the federal system is a } \\
\text { solution to the Anglophone crisis }\end{array}$ \\
\hline \multirow{3}{*}{ Gender } & Pearson Correlation & 1 & .151 & -.228 & -.118 & .120 \\
\hline & Sig. (2-tailed) & & .425 & .225 & .534 & .529 \\
\hline & $\mathrm{N}$ & 30 & 30 & 30 & 30 & 30 \\
\hline \multirow{3}{*}{ Age } & Pearson Correlation & .151 & 1 & -.348 & $-.626^{* *}$ & .184 \\
\hline & Sig. (2-tailed) & .425 & & .059 & .000 & .331 \\
\hline & $\mathrm{N}$ & 30 & 30 & 30 & 30 & 30 \\
\hline \multirow[t]{2}{*}{ Religion } & Sig. (2-tailed) & .225 & .059 & & .008 & .000 \\
\hline & $\mathrm{N}$ & 30 & 30 & 30 & 30 & 30 \\
\hline \multirow{3}{*}{ Occupation } & Pearson Correlation & -.118 & $-.626^{* *}$ & $.474^{* *}$ & 1 & -.146 \\
\hline & Sig. (2-tailed) & .534 & .000 & .008 & & .442 \\
\hline & $\mathrm{N}$ & 30 & 30 & 30 & 30 & 30 \\
\hline \multirow{3}{*}{$\begin{array}{l}\text { Do you think the federal } \\
\text { system is a solution to the } \\
\text { Anglophone crisis }\end{array}$} & Pearson Correlation & .120 & .184 & $-.682^{* *}$ & -.146 & 1 \\
\hline & Sig. (2-tailed) & .529 & .331 & .000 & .442 & \\
\hline & $\mathrm{N}$ & 30 & 30 & 30 & 30 & 30 \\
\hline
\end{tabular}

**. Correlation is significant at the .01 level (2-tailed). 
Table 8. The relationship between demographic factors and the unitary system as a solution to the Anglophone crisis.

\begin{tabular}{|c|c|c|c|c|c|c|}
\hline \multicolumn{7}{|c|}{ Correlations } \\
\hline & & Gender & Age & Religion & Occupation & $\begin{array}{l}\text { Do you think the Unitary system is a } \\
\text { solution to the Anglophone crisis }\end{array}$ \\
\hline \multirow{3}{*}{ Gender } & Pearson Correlation & 1 & .151 & -.228 & -.118 & -.071 \\
\hline & Sig. (2-tailed) & & .425 & .225 & .534 & .708 \\
\hline & $\mathrm{N}$ & 30 & 30 & 30 & 30 & 30 \\
\hline \multirow{3}{*}{ Age } & Pearson Correlation & .151 & 1 & -.348 & $-.626^{* *}$ & .130 \\
\hline & Sig. (2-tailed) & .425 & & .059 & .000 & .492 \\
\hline & $\mathrm{N}$ & 30 & 30 & 30 & 30 & 30 \\
\hline \multirow{3}{*}{ Religion } & Pearson Correlation & -.228 & -.348 & 1 & $.474^{* *}$ & -.106 \\
\hline & Sig. (2-tailed) & .225 & .059 & & .008 & .577 \\
\hline & $\mathrm{N}$ & 30 & 30 & 30 & 30 & 30 \\
\hline \multirow{3}{*}{ Occupation } & Pearson Correlation & -.118 & $-.626^{* *}$ & $.474^{* *}$ & 1 & .068 \\
\hline & Sig. (2-tailed) & .534 & .000 & .008 & & .719 \\
\hline & $\mathrm{N}$ & 30 & 30 & 30 & 30 & 30 \\
\hline \multirow{3}{*}{$\begin{array}{l}\text { Do you think the Unitary system is a } \\
\text { solution to the Anglophone crisis }\end{array}$} & Pearson Correlation & -.071 & .130 & -.106 & .068 & 1 \\
\hline & Sig. (2-tailed) & .708 & .492 & .577 & .719 & \\
\hline & $\mathrm{N}$ & 30 & 30 & 30 & 30 & 30 \\
\hline
\end{tabular}

**. Correlation is significant at the .01 level (2-tailed).

\subsection{The Relationship between Demographic Factors and the Republic as a Solution to the Anglophone Crisis}

Table 9 illustrates, the relationship between the Republic of Cameroon and demographic factors as a solution. The relationship is significant, thus in 1984, President Pual Biya changed the system of Government, from a Unitary system to the Republic of Cameroon, meaning the Cameroon is moving backwards. The French speaking part of Cameroon gained her independence in 1960 with the name La Republic Du Cameroon. A majority of the French speaking Cameroonians are in favor of this system meaning they are benefitting from the system. As for the two English speaking regions, this system means recolonization, suppression, oppression, corruption mismanagement amongst others. Some say it's a failed system.

\subsection{The Relations between Demographic Factor and Secession}

Amongst all Table 10, show the relationship between demographic factors and secession. Secession is the last option according to May Anglophones. The crisis in Cameroon today started with lawyers and teachers complaining about the misuse of English language and destruction of the English culture. But with the heavy hand of the government in managing the crisis made politicians to politicize the course of the crisis to the angle of secession, which came as the last option. 
Table 9. The relationship between demographic factors and the republic as a solution to the Anglophone crisis.

\begin{tabular}{|c|c|c|c|c|c|c|}
\hline \multicolumn{7}{|c|}{ Correlations } \\
\hline & & Gender & Age & Religion & Occupation & $\begin{array}{l}\text { Do you think Cameroon as s Republic } \\
\text { is a solution to the Anglophone crisis }\end{array}$ \\
\hline \multirow{3}{*}{ Gender } & Pearson Correlation & 1 & .151 & -.228 & -.118 & -.200 \\
\hline & Sig. (2-tailed) & & .425 & .225 & .534 & .288 \\
\hline & $\mathrm{N}$ & 30 & 30 & 30 & 30 & 30 \\
\hline \multirow{3}{*}{ Age } & Pearson Correlation & .151 & 1 & -.348 & $-.626^{* *}$ & -.244 \\
\hline & Sig. (2-tailed) & .425 & & .059 & .000 & .194 \\
\hline & $\mathrm{N}$ & 30 & 30 & 30 & 30 & 30 \\
\hline \multirow{3}{*}{ Religion } & Pearson Correlation & -.228 & -.348 & 1 & $.474^{* *}$ & .274 \\
\hline & Sig. (2-tailed) & .225 & .059 & & .008 & .142 \\
\hline & $\mathrm{N}$ & 30 & 30 & 30 & 30 & 30 \\
\hline \multirow{3}{*}{ Occupation } & Pearson Correlation & -.118 & $-.626^{* *}$ & $.474^{* *}$ & 1 & .163 \\
\hline & Sig. (2-tailed) & .534 & .000 & .008 & & .389 \\
\hline & $\mathrm{N}$ & 30 & 30 & 30 & 30 & 30 \\
\hline Do you think Cameroon as $s$ & Pearson Correlation & -.200 & -.244 & .274 & .163 & 1 \\
\hline Republic is a solution to the & Sig. (2-tailed) & .288 & .194 & .142 & .389 & \\
\hline Anglophone crisis & $\mathrm{N}$ & 30 & 30 & 30 & 30 & 30 \\
\hline
\end{tabular}

**. Correlation is significant at the .01 level (2-tailed).

Table 10. The relations between demographic factor and secession.

\begin{tabular}{|c|c|c|c|c|c|c|}
\hline \multicolumn{7}{|c|}{ Correlations } \\
\hline & & Gender & Age & Religion & Occupation & $\begin{array}{c}\text { Do you think secession is a solution to } \\
\text { the Anglophone crisis }\end{array}$ \\
\hline \multirow[b]{2}{*}{ Gender } & Pearson Correlation & 1 & .151 & -.228 & -.118 & .018 \\
\hline & Sig. (2-tailed) & & .425 & .225 & .534 & .923 \\
\hline \multirow{3}{*}{ Age } & Pearson Correlation & .151 & 1 & -.348 & $-.626^{* *}$ & -.084 \\
\hline & Sig. (2-tailed) & .425 & & .059 & .000 & .658 \\
\hline & $\mathrm{N}$ & 30 & 30 & 30 & 30 & 30 \\
\hline \multirow{2}{*}{ Religion } & Pearson Correlation & -.228 & -.348 & 1 & $.474^{* *}$ & -.004 \\
\hline & $\mathrm{N}$ & 30 & 30 & 30 & 30 & 30 \\
\hline \multirow{3}{*}{ Occupation } & Pearson Correlation & -.118 & $-.626^{* *}$ & $.474^{* *}$ & 1 & -.042 \\
\hline & Sig. (2-tailed) & .534 & .000 & .008 & & .826 \\
\hline & $\mathrm{N}$ & 30 & 30 & 30 & 30 & 30 \\
\hline \multirow{3}{*}{$\begin{array}{c}\text { Do you think secession is a } \\
\text { solution to the Anglophone } \\
\text { crisis }\end{array}$} & Pearson Correlation & .018 & -.084 & -.004 & -.042 & 1 \\
\hline & Sig. (2-tailed) & .923 & .658 & .982 & .826 & \\
\hline & $\mathrm{N}$ & 30 & 30 & 30 & 30 & 30 \\
\hline
\end{tabular}

**. Correlation is significant at the .01 level (2-tailed). 


\section{Discussion}

The research presented in this paper analysis the Anglophone crisis: the birth of Warlords, the outcome and possible solutions to the crisis in the two English speaking regions and the entire country. This research puts more pressure in finding solutions to the ongoing crisis in Cameroon. Cameroon is a bilingual country with more than $80 \%$ of the country speaking French and most likely live in the Francophone Zones as they call it. The two English regions (Anglophones) over the years have been complaining to the government about, issues of marginalization, suppression, corruption, and even black to black colonization amongst others. The Anglophone Crisis today can be described as the expression of an acute, aggravated, long standing tension that is existing between the two English regions and the Republic of Cameroon.

The detailed findings, reveals that different forms of government can be used as a model to solve the Anglophone crisis. This article brings out the advantages of different Forms of government and how beneficial it can be used as a solution to the Anglophone crisis, also the article also analysis other related factors which can also be used as a solution to the Anglophone crisis. The article also points out that Cameroon like most African countries, have the tendency to use the military to solve burning issues concerning the socio political, economic and cultural wellbeing of most Africans. The finding, to a greater extend can be used as a guide to reformulate, reorganized and to restructure the different forms of governments in Africa.

The findings show that in the context of Cameroon, a two-state Federation, is the most suitable form of government which can be employed to solve the long standing Anglophone crisis. In 1961, the West Cameroon (the Southern Cameroon) and the East Cameroon (La Republic Du Cameroon) came together to form a Federal government. Thus, this form of government will not be a trial but success as analyzed by the study. In addition, Cameroon like most African countries, if they should adopt any of the aforementioned forms of government, they should have a strong foresight of the historical, cultural, political and socio economic background of their respective countries.

Findings on which system of government that will suit the Cameroon system as to better manage the Anglophone crisis also reviews that, most African government pay little attention concerning decision that will better governed their respective countries. For instance, Sudan and Cameroon, these countries relied on a dictatorial regime where the use of military force is the main instrument in managing peace and order in the country. This system, only led to misery and continues war, which became an international crisis. Secession was the only system that was implemented that brought peace in Sudan, thus an option for Cameroon.

The research also shows that, the structure of bilingualism in Cameroon reveals, French and English to be the official languages of country. In theory it's applicable, but in practice, it's faulty. Most of the official document in Cameroon 
are in French. This give had time for the Anglophones to be represented even in top positions like the parliament. Videos circulated on the social media, when in one occasion the president of the lower house of parliament refused Anglophone parliamentarians not to address their issues in English. Both the Educational, health and the judicial sectors are heavily under represented by Anglophone staffs in the Anglophone region of the country.

The findings also review that, an open political dialogue, between state and its citizens on which system of government they will prefer is an ideal solution for the Anglophone crisis. For the case of Sudan, they had decades of civil war destroying thousands of lives and property before they had a plebiscite. The people of South Sudan voted for secession on the $9^{\text {th }}$ of July 2011. On the other hand, Cameroon on her part had a plebiscite on the 11 February 1961 with west Cameroon joining the East Cameroon. The option of secession was not represented on the day of plebiscite. The finding also shows that dialogue between the government and her citizens opens the government to possible solutions to redress burning issues. In the case of Cameroon, the $30^{\text {th }}$ September 2019 National dialogue finalizes with the Anglophones having a special status.

The research also proves that most Cameroonians, do not really trust the international organizations like the United Nation and African Union in managing conflict situations. From the findings, the UN and AU only intervene in situation when it's more than the abuse of Human Right. The case of Rwanda, Sudan, Liberia, and presently Cameroon were highlighted as cases where the international community took the position as observers. In Cameroon the UN is managing the issues of refugee, those internally and externally displaced. The $\mathrm{UN}$ and $\mathrm{AU}$, have limited powers to handle issues in Cameroon and Africa as whole, since most of the African leaders are dictators who don't even believe in human rights and freedom.

\section{Recommendations and Conclusion}

The main purpose of this research was to look for possible solutions to the Anglophone crisis which will solve the issue of the rise of warlords and the impact of their activities. From the findings, it was found out that Federalism, Unitary system, Cameroon as a Republic and even secession were relatively significant propositions as solutions to the Anglophone crisis. Also, the demographic factors were statistically significant to the different forms of government. A correlation was done, and was realized that the demographic factors were highly associated with each other not only in terms of $(p)$ values but also in terms of absolute values, thus rejecting the null hypothesis which states there is no relationship between the demographic factors and the different forms of government. The study therefore stipulates that there is a significant relationship between demographic factors and the different forms of government.

To a limited extend, the research presented in this article adds greater weight to the needs to further explore different strategies that can be used in managing 
the Anglophone crisis. Using Cameroon as the case study gives a good insight in understanding how different forms of government can be used as a solution to crisis like the Anglophone crisis.

Furthermore, bringing a solution to the Anglophone crisis will mean building trust and community between the Government and the Community of NW and SW region of Cameroon. This type of commitment will mean engraving institutions that will respond to emergencies such as the teachers and lawyer's demonstration of 2016.

In that context, the following are emergency steps that should be taken without hesitation.

- The president of the Republic of Cameroon should publicly recognize the Anglophone problem as to calm down tension in the country.

- All the leaders of the Anglophone movement should be released, and all those who have been sent on exile because of the crisis should be welcome back home.

- All those who have committed crime against humanity should be sanctioned.

- The Cameroon government, should re-organize both the local and senior administrative institutions of Cameroon as to better represent and reflect the demographic, political and historical importance of the Anglophones in Cameroon, to welcome youth and more legitimate members of the Anglophone community.

- Furthermore, the National Commission on Bilingualism and Multiculturalism should also be restructured and organized so that both the Anglophones and Francophone should be represented equally so that both parties will have equal power in decision making.

\section{Conflicts of Interest}

The author declares no conflicts of interest regarding the publication of this paper.

\section{References}

Abah, I. (2018). 4000 Persons in Batibo Displaced after Deadly Clashes between Gunmen and Security Forces.

https://www.journalducameroun.com/en/4000-persons-batibo-displaced-deadly-clashe s-gunmen-security-forces/

Anyangwe, C. (2009). Betrayal of Too Trusting a People. The UN, the UK and the Trust Territory of the Southern Cameroons: The UN, the UK and the Trust Territory of the Southern Cameroons. In C. Anyangwe (Ed.), Betrayal of Too Trusting a People (pp. 108-111). New York: African Books Collectives.

Bareta, M. (2018). NEWS Interim Government Warns Cameroun against Propagating Inter-Citizen War between Both Cameroons. https://www.bareta.news/author/baramarkofficial/

Bhattacherjee, A. (2012). Social Science Research: Principles, Methods, and es. TTampa, FL: University of South Florida.

Cameroun News Agency (2018). No Retreat, No Surrender, From Defensive to Offensive 
Strategy, the Way Forward In 2019-Dr Samuel Sako.

https://cameroonnewsagency.com/no-retreat-no-surrender-from-defensive-to-offensiv e-strategy-the-way-forward-in-2019-dr-samuel-sako/

Cameroun, J. (2018a). Cameroon: Anglophone Detainees Missing after Kondengui Protests.

https://www.journalducameroun.com/en/cameroon-anglophone-detainees-missing-aft er-kondengui-protests/

Cameroun, J. (2019a). Cameroon: Ambazonia “Colonel” Killed in Muyuka. https://web.archive.org/web/20190207020111/ https://www.journalducameroun.com/en/cameroon-ambazonia-colonel-killed-in-muy uka/

Cameroun, J. D. (2018b). Cameroon Soldiers Kill 13 Separatist Fighters in Binka. https://www.journalducameroun.com/en/cameroon-soldiers-kill-13-separatist-fighters -in-binka/

Cameroun, J. D. (2018c). Cameroon: “Ambazonia General” Killed in Kumba. https://www.journalducameroun.com/en/cameroon-ambazonia-general-killed-in-kum $\underline{\mathrm{ba} /}$

Cameroun, J. D. (2018d). Cameroon: Principal of PSS Nkwen, Three Others Released. https://www.journalducameroun.com/en/cameroon-principal-of-pss-nkwen-three-oth ers-released/

Cameroun, J. D. (2019b). Cameroon: “Ambazonia General” Killed in Matoh. https://web.archive.org/web/20190125020522/

https://www.journalducameroun.com/en/cameroon-ambazonia-general-killed-in-matoh/

Cameroun, J. D. (2019c). Cameroon: Ambazonia Activists Divided over "Ten-Day Lockdown".

https://www.journalducameroun.com/en/cameroon-ambazonia-activists-divided-overten-day-lockdown/

Cameroun, J. D. (2019d). Cameroon: Paul Biya Ready for Dialogue to End Anglophone Crisis, PM Says.

https://www.journalducameroun.com/en/cameroonpaul-biya-ready-for-dialogue-to-en d-anglophone-crisis-pm-says/

Cameroun, J. D. (2019e). Cameroon: Violence, Gunshots, Ghost Towns Engulf Parts of Anglophone Towns.

https://www.journalducameroun.com/en/cameroon-vionlence-gunshots-ghost-townsengulf-parts-of-anglophone-towns/

Concord, C. (2018). Anglophe Crisis. Three Soldiers Killed in Mbonge. https://web.archive.org/web/20180507045116/

http://www.cameroon-concord.com/boko-haram/anglophone-crisis-three-soldiers-kill ed-in-mbonge

Creswell, P. C. (2011). Best Practices for Mixed Methods Research in the Health Sciences. New York: New York University. https://doi.org/10.1037/e566732013-001

Dahir, A. 1. (2018). Cameroon's Anglophone Crisis Is Threatening to Spin out of Control. Quartz Africa, 14 January, 10.

Etikan (2016). Comparison of Convenience Sampling and Purposive Sampling. American Journal of Theoretical and Applied Statistics, 5, 1-4. https://doi.org/10.11648/j.ajtas.20160501.11

Guardian, T. (2018). "This Is a Genocide”: Villages Burn as War Rages in Blood-Soaked Cameroon.

https://www.theguardian.com/global-development/2018/may/30/cameroon-killings-es 
calate-anglophone-crisis

Guradian, T. (2018). Gunfire in Cameroon's Anglophone Regions Deters Voters on Polling Day.

https://www.theguardian.com/world/2018/oct/07/gunfire-in-cameroons-anglophone-r egions-deters-voters-on-polling-day

Jazeera, A. (2018). Cameroon Teachers, Lawyers Strike in Battle for English.

http://www.aljazeera.com/news/2016/12/cameroon-teachers-lawyers-strike-english-16 1205095929616.html

Konings, P. (2005). Negotiating an Anglophone Identity. A Study of the Politics of Recognition and Representation in Cameroon. Yaounde: Cahiers d'Études Africaines.

Moki, E. K. (2018). Separatists Kidnap 79 Pupils in Cameroon's Restive Northwest. https://www.wsfa.com/2018/11/05/armed-men-kidnap-students-cameroon-restive-nor thwest/

Nationalia (2017). Southern Cameroon Crisis Has Marginalized Anglophones Seeking Independent Republic.

https://www.nationalia.info/new/10912/2017-calendar-of-elections-around-the-world

Nchoji, N. P. (2015). The Anthropology of Africa: Challenges for the 21st Century. New York: African Books Collectives.

Searcey, D. (2018). Cameroon on Brink of Civil War as English Speakers Recount "Unbearable" Horrors.

https://www.nytimes.com/2018/10/06/world/africa/cameroon-election-biya-ambazonia .html

V.O.A. (2018). Cameroon Says Military Casualties Mounting. https://web.archive.org/web/20180628015704/

https://www.voanews.com/a/cameroon-says-military-casualties-mounting/4456739.ht $\underline{\mathrm{ml}}$

V.O.A. (2019a). Thousands Flee Violence in Cameroon's English-Speaking Regions. https://www.voanews.com/africa/thousands-flee-violence-cameroons-english-speaking -regions

V.O.A. (2019b). Cameroon Separatists Celebrate "Independence" as Dialogue Is Held. https://www.voanews.com/africa/cameroon-separatists-celebrate-independence-dialog $\underline{\text { ue-held }}$ 